\title{
Differences in attitudes toward internet usage - empirical study from Serbia
}

\author{
Đorđe Ćelić
}

Faculty of Technical Sciences, University of Novi Sad, Novi Sad, Serbia

Zoran Drašković

Faculty of Technical Sciences, University of Novi Sad, Novi Sad, Serbia

Zorica Uzelac

Faculty of Technical Sciences, University of Novi Sad, Novi Sad, Serbia

Viktorija Petrov

Faculty of Economics, University of Novi Sad, Novi Sad, Serbia

\begin{abstract}
The most influential trend, which has emerged as a result of the development of information and communication technologies, is business over the internet. Users of internet, and especially mobile internet, are mostly young people from $20+$ to $30+$ years of age. Marketing experts and researchers call these new users: "Generation Y", "Millennials", or "Net generation". This study analyzes consumer's attitude towards four constructs: perception of mobile internet ubiquity (time and spatial flexibility); use of internet - instant gratification; use of internet - product variety; and use of internet - riskiness. Research hypotheses were tested by analyzing data collected from a sample of 521 respondents from Serbia. Statistically significant differences according to age, gender, and education level of respondents were found. Considering the nature of the internet that allows reaching customers all over the world a better understanding of the attitudes of young internet users from Serbia.
\end{abstract}

\section{Keywords}

Internet shopping, Generation Y, attitudes toward the internet, mobile internet ubiquity.

\section{Introduction}

In the knowledge economy, the contours of knowledge organization are expanding and encompassing both buyers and suppliers. As part of the research of knowledge economy and knowledge organization, great interest exists in the changes that relate to buyers and users of products and services offered by knowledge organizations. In order to survive in the global economy, organizations must improve their products and services using their intellectual capital through a dynamic network of knowledge exchange both inside and outside of their borders. Improving information and communication channels between the organization and its environment enables discovery of new entrepreneurial opportunities (Shane \& Venkataraman, 2000), so developing relationships with customers and suppliers is of great impor- tance (Ardichvili, Cardozo \& Ray, 2003; Koryak et al., 2015).

Knowledge management in the organization goes through a period of transformation in a direction that is oriented towards the customer (Taghizadeh, Rahman \& Hossain, 2018), under a recognizable name Customer Knowledge Management.

In addition to treating customers as a significant source of knowledge (Gibbert, Leibold \& Probst, 2002), it becomes important to understand their relationship to new trends in order to better satisfy their needs. Thus, the buyer becomes an active creator and an equal partner in the process of adding value to the products and services of the organization. One of the most influential trends, which has emerged as a result of the development of information and communication technologies, is doing business over the internet. There is a lot 
of research that deals with the factors of the influence of the internet and digital strategies on business operations.

Users of internet and mobile internet are mostly young people. Marketing experts and researchers call these new users Generation Y, Millennials, Net generation, etc. Members of Generation Y, young people in their 20's and 30's, are the first generation that hasn't experienced the world without internet, they are internet surfing masters, online connectivity champions, the first generation in history whose members measure the number of acquaintances in hundreds and thousands.

This paper examines the views of buyers in Serbia that belong to the Generation $\mathrm{Y}$ in the context of the use of internet and mobile internet. User opinions were analyzed in relation to the four constructs: Ubiquity of the mobile internet spatial and temporal flexibility; Use of the internet - instant gratification; Use of the internet - variety of products; Use of the internet - riskiness.

The main objective of this research was to measure attitudes, primarily of young internet users, towards the use of internet and mobile internet, and to examine whether there were statistically significant differences in attitudes in terms of gender, age and level of education. In line with the research objectives, hypotheses have been defined:

Hypothesis 1: There are statistically significant differences among genders in their attitudes towards the usage of the internet.

Hypothesis 2: There are statistically significant differences among respondents of different age in their attitudes towards the usage of the internet.

Hypothesis 3: There are statistically significant differences among respondents of different education levels in their attitudes towards the usage of the internet.

Research hypotheses were tested by analyzing data collected from a sample of 521 respondents from Serbia. Statistically significant differences in attitudes of the respondents regarding the use of the internet and mobile internet in terms of age, sex and level of education, were determined.

\section{Theoretical framework}

In this part of the paper we define constructs in relation to which the attitudes of internet users belonging to the Generation Y are analyzed, and we give a review of the literature from which the constructs were adopted.

\subsection{Ubiquity of the mobile Internet - spatial and temporal flexibility}

Ubiquity of the mobile internet - spatial and temporal flexibility is a unique feature of mobile phones (Barnes \& Huff, 2003), because mobile phone can be used at any time almost everywhere. Okazaki, Li \& Hirose, (2009) defined the perception of ubiquity as the extent to which a person believes that the ability to access the internet with a mobile phone gives him spatial and temporal flexibility. Information technology is characterized by three constraints in the context of time and space: connection, which requires the presence of users at a specific time and place; ability, which refers to the resources of the user and his capacity to overcome the spatial separation at a particular moment; time and spatial zones, which restrict access to certain services at a particular point in time. Ubiquity of the mobile internet allows the user to overcome all three of these restrictions.

Questionnaire for measuring attitudes towards ubiquity of the mobile internet was developed by Okazaki, Li \& Hirose (2009), whereby part of the questionnaire relating to time flexibility was adopted from the work of the authors Mathwick, Malhotra \& Rigdon (2002).

Three items in this questionnaire measure the extent to which a person believes that the ability to access the internet using a mobile phone gives him spatial flexibility (Okazaki et al., 2009):

- I1 - Using the mobile internet I can get information wherever I am;

- I2 - The use of mobile internet gives me the opportunity to overcome spatial constraints;

- I3 - Browsing websites via the mobile internet is possible in every location, wherever I am.

Two items in this questionnaire measure the extent to which a person believes that the ability to access the internet with a mobile phone gives him time flexibility (Mathwick et al., 2002):

- I4 -Use of the mobile internet is an effective way of using my time;

- I5 -Browsing websites via the mobile internet fits my schedule.

\subsection{Internet usage - Instant Gratification}

The results of previous researches show that experience of pleasure or hedonistic motives also affect buying, and shopping behavior (Arnold \& Reynolds, 2003; Bellenger \& Pradeep, 1980; Ridgway, Dawson, \& Bloch, 1990). Hedonistic 
motives relate to positive feelings, a sense of pleasure and excitement, which the customer feels as he shops or buys. Positive feelings that a consumer has during shopping motivate him to buy more. Instant positive feeling relates primarily to the process of shopping and buying, rather than to the specific delivery or use of the product (KukarKinney, Ridgway, \& Monroe, 2009). The experience of online shopping can trigger these positive feelings faster than shopping in the physical stores, and in this way it can quickly improve the negative mood of the consumer.

The questionnaire for measuring the extent to which the consumer, because of the instant positive feelings he has experienced, rather buys over the internet than in retail facilities, was developed by Kukar-Kinney et al.(2009). The authors developed this and other scales in an effort to better understand compulsive buying and shopping on the internet. Starting with 22 items, the survey was conducted on a sample of 314 buyers at online women's clothing stores. After the reduction of the items, the remaining 16 items formed four factors, one of which was related to instant gratification, and consisted of the following four items:

- I6 - I can more quickly satisfy my need to shop and buy;

- I7 - I can instantly get pleasure from buying;

- I8 - Shopping via the internet can get me out of bad mood faster;

- I9 - Shopping over the internet is more exciting.

\subsection{Internet usage - product variety}

Among the motives for online shopping, a significant positive correlation has been established between the "variety of information and products" and shopping. Many authors examined behavior of obsessive buyers. Obsessive buyers want to experience positive, stimulating feelings while shopping (Faber \& O'Guinn, 1992). When unhappy, obsessive buyers can improve their mood quickly by shopping over the internet, given the diversity of information and products (Ridgway, Kukar-Kinney \& Monroe, 2008). Greater variety gives consumers a greater chance to experience positive feelings as it offers more exciting shopping (McAlister \& Pessemier, 1982). The internet allows consumers to view and buy products at many different stores with many different brands, which is not possible in traditional stores. Positive correlation in motivation for buying and shopping over the internet was determined in the paper by Kukar-Kinney et al. (2009). These results can be helpful when it comes to segmentation of customers, and the intention to understand the reasons why a consumer chooses an 'online' or 'offline' sales channel.

A questionnaire with five items for measuring the extent to which the consumer (due to the range of products available for purchase as well as information about them) prefers buying online to buying in retail stores, was developed by KukarKinneyet al., (2009):

- $\mathrm{I} 10$ - There is greater selection of products;

- I11- There is a greater selection of places where you can buy;

- I12- It is easier to find things I like available in the right size;

- I13- I like to review many products in a short time;

- I14 - I can get a lot of information in a short time.

\subsection{Internet usage - riskiness}

This construct measures the degree to which a person sees his or her various internet activities as a potential threat to his or her privacy, especially when buying online. Schlosser, White \& Lloyd, (2006) suggest that a distinction be made between persons that use internet for searching (searchers), and those that use internet for browsing (browsers). Introducing the distinction between searching and browsing has important implications for the link between the investment in the website and the intentions for online buying (Schlosser et al, 2006).

In their study Schlosser et al. (2006) investigated intentions towards buying by persons doing online searching. As the aim of this research was to anticipate intentions for buying at an online store, the authors focused on people searching over the internet and whose goals could be described as buying consideration. This study states that the intentions of those searching over the internet with the goal to buy are more influenced by their confidence in the company's ability than by their confidence in the benevolence and integrity of the company. The consequence of this study is the conclusion that investments in website, which affirm the ability of the company, have a greater impact on those who search over the internet than their statements concerning the benevolence and integrity of the company (privacy / security statements). 
A seven item questionnaire for measuring degree to which a person views various online activities as potential threats to security and/or privacy, especially when shopping for products, was developed by Schlosser et al., (2006) as a part of another research presented in that paper:

- I15 - Shopping online is risky;

- I16 - Providing credit card information online is risky;

- I17 - Providing personal information online is risky;

- I18 - Buying things on line is risky;

- I19 - Giving my e-mail address and phone number online is risky;

- I20 - Online registration is risky;

- I21 - It is riskier to shop online than offline for a product.

\section{Research methodology}

\subsection{Instrument}

A structured questionnaire was developed in order to collect data on the views of internet users. All constructs and related items used in the questionnaire were adopted from published studies and linguistically adapted. The questionnaire was structured in the following way: in the first part of the questionnaire, general demographic data (gender, age and level of education) were required; in the second part of the questionnaire were questions regarding attitudes towards use of mobile internet and internet. The second part of the questionnaire contained 21 items that measured four constructions of attitudes (constructs) regarding the use of internet: ubiquity of mobile internet spatial and temporal flexibility (5 items); Internet usage - instant gratification (4 items); internet usage - product variety ( 5 items); and internet usage - riskiness ( 7 items). In order to determine the attitudes of the respondents, we measured all multi-item constructs using the seven-point Likert's scale with anchors "I disagree completely" (=1) and "I agree completely" (=7). All of the items were positively formulated.

\subsection{Sample}

The questionnaire was distributed online and a call for participation in the research was sent through the MailChimp marketing platform to 1500 randomly selected former and current students of the Faculty of Technical Sciences at the University of Novi Sad. During the period from November 2016 until March 2017, a total of 521 valid responses to the questionnaire were collected. Out of the total number of respondents 462 $(88.7 \%)$ were under the age of $26 ; 24(4.6 \%)$ were older than 26 but under the age of 30 ; and 35 $(5.7 \%)$ were above the age of 30 . When it comes to gender, $198(38 \%)$ of respondents were male, and $323(62 \%)$ were female.

In relation to the highest level of education, the highest number of respondents completed secondary education (353 or $67.8 \%$ ); 2 year college (39 or $7.5 \%$ ); bachelor's degree (82 or $15.7 \%$ ); master's degree or $\mathrm{PhD}$ (47 or 9\%).

\section{Research results}

All the theoretical concepts used in this study were adopted from previous studies published in scientific literature, and they provide the theoretical and rational framework of this research. Due to the fact that items for the measurement of attitudes regarding the use of the internet were not taken from just one source, we first performed principal component analysis to confirm theoretical constructs. For the analysis of the justification for the application of factor analysis, the KMO (Kaiser-Mayer-Olkin) test, and the Bartlett test were used. The KMO indicator value is 0.915 which exceeds the recommended value of 0.5 . Bartlett's test of sphericity achieved statistical significance $\left(\chi^{2}=9623.012 ; p=0.000<0.05\right)$, thus fulfilling the conditions for justification of the application of factor analysis.

The Principal Components Factor Analysis was applied and the number of main components was determined using criteria based on characteristic values (Kaiser criterion) according to which only factors that have an eigenvalue greater than 1 were included in the promax oblique rotation. The results demonstrated formation of four components (factors) and they coincided with the results obtained by using the Scree plot based criterion. All items (except the item I6 in Factor 4 which had loading 0.5 ) had loadings greater than 0.75 . That is considered to be a strong correlation, proving that each construct is strongly linked to its set of interrelated items, i.e. that the validity of the construct can be considered appropriate. The items are, as indicated in the literature, grouped into factors (components) that form the dimensions of attitudes towards the use of internet:

Factor 1 - Riskiness: the eigenvalue of the most influential factor is 8.935 and it explains $42.547 \%$ variance. Item with the highest factor loading is: I19 - Giving my e-mail address and 
phone number online is risky, followed by I18 Buying things online is risky, and I20 - Online registration is risky, followed by others presented in Table 1.
The reliability of the subscales was evaluated by means of the Cronbach's alpha coefficient: 0.944 , which means that instrument is reliable (Table 1).

Table 1 Principal Component Factor Analysis

\begin{tabular}{|c|c|c|c|c|c|c|c|c|}
\hline & \multicolumn{2}{|c|}{ Factor 1-Riskiness } & \multicolumn{2}{|c|}{$\begin{array}{l}\text { Factor 2-Product } \\
\text { variety }\end{array}$} & \multicolumn{2}{|c|}{ Factor 3- Ubiquity } & \multicolumn{2}{|c|}{$\begin{array}{c}\text { Factor 4- } \\
\text { Instant gratification }\end{array}$} \\
\hline \multirow{8}{*}{$\begin{array}{l}\text { Factor charac- } \\
\text { teristics }\end{array}$} & items & loadings & items & loadings & items & loadings & items & loadings \\
\hline & 115 & 0.830 & 110 & 0.926 & 11 & 0.876 & 16 & 0.501 \\
\hline & 116 & 0.836 & 111 & 0.936 & 12 & 0.914 & 17 & 0.824 \\
\hline & 117 & 0.865 & 112 & 0.876 & 13 & 0.792 & 18 & 0.922 \\
\hline & 118 & 0.902 & 113 & 0.795 & 14 & 0.851 & 19 & 0.826 \\
\hline & 119 & 0.938 & 114 & 0.837 & 15 & 0.848 & & \\
\hline & 120 & 0.906 & & & & & & \\
\hline & 121 & 0.754 & & & & & & \\
\hline Eigenvalue & \multicolumn{2}{|c|}{8.935} & \multicolumn{2}{|c|}{6.91} & \multicolumn{2}{|c|}{6.67} & \multicolumn{2}{|c|}{4.45} \\
\hline$\%$ variance & \multicolumn{2}{|c|}{$42.547 \%$} & \multicolumn{2}{|c|}{$19.179 \%$} & \multicolumn{2}{|c|}{$8.432 \%$} & \multicolumn{2}{|c|}{$5.933 \%$} \\
\hline Cronbach's a & \multicolumn{2}{|c|}{0.944} & \multicolumn{2}{|c|}{0.928} & \multicolumn{2}{|c|}{0.909} & \multicolumn{2}{|c|}{0.871} \\
\hline
\end{tabular}

Factor 2 - Product variety: the eigenvalue of the second factor is 6.91 and it explains $19.179 \%$ of the variance. Item with the highest factor loading is: I11 - There is greater selection of places where you can buy, followed by: I10 - There is greater selection of products and so forth as presented in Table 1.

The reliability of the subscales was evaluated by means of the Cronbach's alpha coefficient: 0.928 , which means that instrument is reliable (Table 1).

Factor 3 - Ubiquity: the eigenvalue of the third factor is 6.67 and it explains $8.432 \%$ of the variance.

Item with the highest factor loading is: I2 Use of mobile internet gives me opportunity to overcome spatial constraints, followed by: I1 - By using mobile internet I can get information wherever I am, and so forth as presented in Table 1.

The reliability of the subscales was evaluated by means of the Cronbach's alpha coefficient: 0.909 , which means that instrument, is reliable (Table 1).
Factor 4 - Instant gratification: the eigenvalue of the fourth factor is 4.45 and it explains $5.933 \%$ of the variance. Item with the highest factor loading is: I8 - Shopping via the internet can get me out of bad mood faster, followed by: I9 Shopping over the internet is more exciting, and so forth as presented in Table 1 .

The reliability of the subscales was evaluated by means of the Cronbach's alpha coefficient: 0 . 871 , which means that instrument is reliable (Table 1).

In order to test the hypothesis:

Hypothesis 1: There is a statistically significant difference between genders in their attitudes towards the usage of the internet,

the obtained factor scores were tested using the Levene's test for equality of variances and $t-$ test. Statistically significant differences between genders ware determined regarding the mean values calculated for:

- Factor 3 - Ubiquity $(\mathrm{t}=-2.785, \mathrm{df}=519$, $\mathrm{p}<0.01$ ), and

- Factor 1 - Riskiness $(\mathrm{t}=-4.098, \mathrm{df}=519$, $\mathrm{p}<0.01$ ) (Table 2).

Table 2 t-tests of independent samples for gender comparisons; Levene's test for testing equality of variances

\begin{tabular}{c|c|c|c|c|c|c|c}
\hline & $\mathbf{F}$ & Sig. & $\mathbf{t}$ & $\mathbf{d f}$ & $\begin{array}{c}\text { Sig. } \\
\text { (2-tailed) }\end{array}$ & $\begin{array}{c}\text { Mean } \\
\text { Difference }\end{array}$ & $\begin{array}{c}\text { Std. Error } \\
\text { Difference }\end{array}$ \\
\hline F3 & 3.222 & .073 & -2.785 & 519 & .006 & -0.412 & 0.148 \\
\hline F4 & 2.015 & .156 & -.470 & 519 & .639 & -0.064 & 0.135 \\
\hline F2 & 7.321 & .007 & .722 & 371.632 & .471 & 0.113 & 0.156 \\
\hline F1 & 2.969 & .085 & -4.098 & 519 & .000 & -0.555 & 0.136 \\
\hline
\end{tabular}

Source: authors' calculation in SPSS 20.0 based on survey data 
In order to test the hypothesis:

Hypothesis 2: There is a statistically significant difference between respondents of different ages in their attitudes towards the usage of the internet, the obtained factor scores were tested using the Levene's test for equality of variances and t-test. Statistically significant difference between respondents younger than 26 , and respondents older than 30 years of age was determined regarding the mean value calculated for:

- Factor 3 - Ubiquity $(\mathrm{t}=-2.078, \mathrm{df}=498$, $\mathrm{p}<0.05$ ) (Table 3).

Table 3 t-tests of independent samples for comparison of groups of respondents under the age of 26 and over 30 years of age; Levene's test for testing equality of variances

\begin{tabular}{c|c|c|c|c|c|c|c}
\hline & $\mathbf{F}$ & Sig. & $\mathbf{t}$ & $\mathbf{d f}$ & $\begin{array}{c}\text { Sig. } \\
\text { (2-tailed) }\end{array}$ & $\begin{array}{c}\text { Mean } \\
\text { Difference }\end{array}$ & $\begin{array}{c}\text { Std. Error } \\
\text { Difference }\end{array}$ \\
\hline F3 & 3.413 & .065 & -2.078 & 498 & .038 & -.35925719 & .17290971 \\
\hline F4 & .000 & .984 & .272 & 498 & .786 & .04694226 & .17284080 \\
\hline F2 & .966 & .326 & -1.791 & 498 & .074 & -.30969332 & .17290011 \\
\hline F1 & .671 & .413 & -1.383 & 498 & .167 & -.24099339 & .17422887 \\
\hline
\end{tabular}

Source: authors' calculation in SPSS 20.0 based on survey data

In order to test the hypothesis:

Hypothesis 3: There are statistically significant differences among respondents of different education levels in their attitudes towards the usage of the internet,

the obtained factor scores were tested using the Levene's test for equality of variances and ttest. Statistically significant differences between respondents with completed (2 year) college and respondents with completed bachelor's degree were determined regarding the mean values calculated for:

- Factor 3 - Ubiquity $(\mathrm{t}=-3.334, \mathrm{df}=120$, $\mathrm{p}<0.05)$,

- Factor 2 - Product variety $(\mathrm{t}=-3.367$, $\mathrm{df}=120, \mathrm{p}<0.05)($ Table 4$)$

Table 4 t-tests of independent samples for comparison of groups of respondents with completed ( 2 year) college and those with completed bachelor's degree; Levene's test for testing equality of variances

\begin{tabular}{c|c|c|c|c|c|c|c}
\hline & $\mathbf{F}$ & Sig. & $\mathbf{t}$ & $\mathbf{d f}$ & $\begin{array}{c}\text { Sig. } \\
\text { (2-tailed) }\end{array}$ & $\begin{array}{c}\text { Mean } \\
\text { Difference }\end{array}$ & $\begin{array}{c}\text { Std. Error } \\
\text { Difference }\end{array}$ \\
\hline F3 & 22.114 & .000 & -3.334 & 120 & .001 & -.58 & .17 \\
\hline F4 & .366 & .546 & -1.766 & 120 & .080 & -.358 & .202 \\
\hline F2 & 7.503 & .007 & -3.367 & 120 & .001 & -.622 & .1848 \\
\hline F1 & 4.713 & .032 & -1.625 & 120 & .107 & -.314 & .193 \\
\hline
\end{tabular}

Source: authors' calculation in SPSS 20.0 based on survey data

Statistically significant differences between respondents with completed bachelor's degree and those with master's or doctoral degrees were determined regarding the mean values calculated for:
- Factor 4 - Instant gratification $(t=2.337$, $\mathrm{df}=127, \mathrm{p}<0.05)$

- Factor 2 - Product variety $(t=2.435$, $\mathrm{df}=127, \mathrm{p}<0.05)($ Table 5).

Table 5 t-tests of independent samples for comparison of groups of respondents with completed bachelor's degree and those with master's or doctoral degrees; Levene's test for testing equality of variances

\begin{tabular}{c|c|c|c|c|c|c|c}
\hline & $\mathbf{F}$ & Sig. & $\mathbf{t}$ & $\mathbf{d f}$ & $\begin{array}{c}\text { Sig. } \\
\text { (2-tailed) }\end{array}$ & $\begin{array}{c}\text { Mean } \\
\text { Difference }\end{array}$ & $\begin{array}{c}\text { Std. Error } \\
\text { Difference }\end{array}$ \\
\hline F3 & 16.408 & .000 & 1.388 & 127 & .167 & .233 & .167 \\
\hline F4 & 1.447 & .231 & 2.337 & 127 & .021 & .427 & .183 \\
\hline F2 & 4.112 & .045 & 2.435 & 127 & .016 & .417 & .172 \\
\hline F1 & .082 & .775 & .987 & 127 & .326 & .172 & .174 \\
\hline
\end{tabular}

Source: authors' calculation in SPSS 20.0 based on survey data 
A statistically significant difference between respondents who completed secondary education and those who completed ( 2 year) college was determined only for:
- Factor 4 - Instant gratification $(t=2.086$, $\mathrm{df}=522, \mathrm{p}<0.05)($ Table 6).

Table 6 t-tests of independent samples for comparison of groups of respondents with completed secondary and those with (2 year) college education; Levene's test for testing equality of variances

\begin{tabular}{c|c|c|c|c|c|c|c}
\hline & $\mathbf{F}$ & Sig. & $\mathbf{t}$ & $\mathbf{d f}$ & $\begin{array}{c}\text { Sig. } \\
\text { (2-tailed) }\end{array}$ & $\begin{array}{c}\text { Mean } \\
\text { Difference }\end{array}$ & $\begin{array}{c}\text { Std. Error } \\
\text { Difference }\end{array}$ \\
\hline F3 & .133 & .716 & -.228 & 522 & .820 & -.021 & .094 \\
\hline F4 & .038 & .845 & 2.086 & 522 & .037 & .194 & .093 \\
\hline F2 & .262 & .609 & .363 & 522 & .716 & .034 & .093 \\
\hline F1 & .092 & .762 & 1.832 & 522 & .067 & .171 & .093 \\
\hline
\end{tabular}

Source: authors' calculation in SPSS 20.0 based on survey data

\section{Conclusion}

Within this paper we examined attitudes of customers from Serbia, primarily young internet users belonging to the Generation Y, in the context of the use of internet and mobile internet. User attitudes were analyzed in relation to four constructs: Ubiquity of mobile internet - spatial and temporal flexibility; Internet usage - instant gratification; Internet usage - product variety; Internet usage - riskiness. Statistically significant differences were identified in the attitudes of the respondents towards the use of internet and mobile internet depending on the age, gender and level of education. In future research, it would be useful to analyze the identified differences for a better understanding of this customer segment. Given the characteristics of the internet that enable access to customers around the world, better understanding of attitudes towards the use of internet and mobile internet of the young users from Serbia could be of benefit to the business public not only in Serbia, but also globally. Sm

\section{References}

Ardichvili, A., Cardozo, R., \& Ray, S. (2003). A theory of entrepreneurial opportunity identification and development. Journal of Business Venturing, 18 (1), 105-123. https://doi.org/10.1016/S08839026(01)00068-4

Arnold, M. J. \& Reynolds, K. E. (2003). Hedonic shopping motivations. Journal of Retailing, 79 (2), 77-95. https://doi.org/10.1016/S0022-4359(03)00007-1

Barnes, S. J. \& Huff, S. L. (2003). Rising sun:iMode and the wireless Internet. Communications of the ACM, 46 (11), 78-84. https://doi.org/10.1145/948383.948384

Bellenger, D. \& Pradeep, K. (1980). No Title. Journal of Retailing, 56 (3), 77-92.

Faber, R. J. \& O'Guinn, T. C. (1992). A Clinical Screener for Compulsive Buying. Journal of Consumer Research, 19 (3), 459. https://doi.org/10.1086/209315
Gibbert, M., Leibold, M. \& Probst, G. (2002). Five styles of Customer Knowledge Management, and how smart companies use them to create value. European Management Journal, 20 (5), 459-469. https://doi.org/10.1016/S0263-2373(02)00101-9

Koryak, O., Mole, K. F., Lockett, A., Hayton, J. C., Ucbasaran, D. \& Hodgkinson, G. P. (2015). Entrepreneurial leadership, capabilities and firm growth. International Small Business Journal, 33(1), 89-105. https://doi.org/10.1177/0266242614558315

Kukar-Kinney, M., Ridgway, N. M. \& Monroe, K. B. (2009). The Relationship Between Consumers' Tendencies to Buy Compulsively and Their Motivations to Shop and Buy on the Internet. Journal of Retailing, 85 (3), 298307. https://doi.org/10.1016/j.jretai.2009.05.002

Mathwick, C., Malhotra, N. K. \& Rigdon, E. (2002). The effect of dynamic retail experiences on experiential perceptions of value: An Internet and catalog comparison. Journal of Retailing, 78 (1), 51-60. https://doi.org/10.1016/S0022-4359(01)00066-5

McAlister, L. \& Pessemier, E. (1982). Variety Seeking Behavior: An Interdisciplinary Review. Journal of Consumer Research, 9 (3), 311. https://doi.org/10.1086/208926

Okazaki, S., Li, H. \& Hirose, M. (2009). Consumer privacy concerns and preference for degree of regulatory control: A study of mobile advertising in Japan. Special Issue: Advertising Regulation and Self-Regulation. Retrieved from http://ovidsp.ovid.com/ovidweb.cgi?T=JS\&PAGE=refere nce\&D=psyc6\&NEWS=N\&AN=2009-24442-005

Ridgway, N. M., Dawson, S. A. \& Bloch, P. H. (1990). Pleasure and arousal in the marketplace: Interpersonal differences in approach-avoidance responses. Marketing Letters, 1 (2), 139-147. https://doi.org/10.1007/BF00435297

Ridgway, N. M., Kukar-Kinney, M. \& Monroe, K. B. (2008). An Expanded Conceptualization and a New Measure of Compulsive Buying. Journal of Consumer Research, 35 (4), 622-639. https://doi.org/10.1086/591108

Schlosser, A. E., White, T. B. \& Lloyd, S. M. (2006). Converting Web Site Visitors into Buyers: How Web Site Investment Increases Consumer Trusting Beliefs and Online Purchase Intentions. Journal of Marketing, 70 (2), 133-148. https://doi.org/10.1509/jmkg.70.2.133

Shane, S. \& Venkataraman, S. (2000). THE PROMISE OF ENTREPRENEURSHIP as a Filed of Research. 
Academy of Management Review, 25 (1), 217-226. https://doi.org/10.2307/259271

Taghizadeh, S. K., Rahman, S. A. \& Hossain, M. M. (2018). Knowledge from customer, for customer or about

\section{$\triangle$ Correspondence}

Viktorija Petrov

Faculty of Economics in Subotica

Segedinski put 9-11, 24000, Subotica, Serbia

E-mail: viktorija.petrov @ef.uns.ac.rs customer: which triggers innovation capability the most? Journal of Knowledge Management, 22 (1), 162-182. https://doi.org/10.1108/JKM-12-2016-0548 